\title{
KEPEMIMPINAN TRANSFORMATIF DI LEMBAGA PENDIDIKAN
}

\author{
Syafnan \\ Jurusan Da'wah STAIN Padang Sidempuan \\ Korespondensi: Jl. Imam Bonjol KM 4,5 Sihitang - Padang Sidempuan 22722. \\ E-mail: h.syafnanlubis@yahoo.com
}

\begin{abstract}
Leadership so central in attainment a purpose of institute nor organization. Leadership which trust and responsible can bring institute or organization of advance and grows. Leadership also very tightly of its(the bearing with power or power. Prospective leadership determined by the leader becoming top leader from an institute or organization. a leader must have leadership soul having the character of transformatif which sensitive of tehadap change and tunututan its(the area, so that organization led by it is permanent excise and becomes winner in competition of itself change. Leader of education must do orthogonal transformation of leadership through tuition giving, manual and fomentation to led by it that purpose of institute can be reached. Applying of leadership pattern of transformasional can support existence of change of institution-system.
\end{abstract}

Kata kunci: transformatif of leaderships, institution, education

\section{PENDAHULUAN}

$\mathrm{K}$ epemimpinan sangat berperan dalam pencapaian tujuan lembaga atau organisasi. Kepemimpinan yang amanah dan bertanggung jawab dapat membawa lembaga atau organisasi maju dan berkembang. Kepemimpinan juga sangat erat kaitannya dengan power atau kekuasaan. Kepemimpinan yang prospektif ditentukan oleh gaya dan kinerja pemimpin dari suatu lembaga atau organisasi. Pada lembaga pendidikan, pimpinan tertinggi dijabat oleh kepala sekolah, dekan, rektor dan sebagainya. Jabatan ini memerlukan beberapa persyaratan utama yang akan mempengaruhi, mengarahkan dan memimpin lembaga atau organisasinya untuk mencapai tujuan yang telah ditetapkan.

Pemimpin yang profesional harus mempunyai kekuatan untuk memimpin bawahannya, sehingga efektif dalam pekerjaan yang diembannya. Pemimpin yang tidak efektif, tidak akan bisa mencapai tujuan lembaga atau organisasi secara baik. Menurut penulis, banyak ditemukan kepala sekolah, dekan, rektor, yang kurang berhasil melaksanakan tujuan lembaga dan organisasi. Salah satu indiaktornya adalah rendahnya prestasi belajar peserta didik. Selanjutnya, ditemukan kurang disiplinnya pendidik dan tenaga kependidikan di lembaga tersebut.

Pemimpin merupakan motor penggerak yang akan mengendalikan jalannya organisasi mencapai tujuan. Karena, menurut Robbins (1998), kepemimpinan adalah kemampuan mempengaruhi suatu kelompok ke arah pencapaian tujuan. Hasil penelitian menunjukkan diantaranya bahwa kepemimpinan dan motivasi berprestasi kepala sekolah 
berpengaruh secara positif tehadap kinerja guru (Eidwar, 2008); motivasi kerja dan kredibilitas kepala sekolah berkontribusi secara positif terhadap kinerja guru (Yulisna, 2008). Berdasarkan penjelasan diatas, bisa dijelaskan bahwa diperlukan gaya kepemimpinan yang transformatif untuk pengembangan lembaga kependidikan. Artikel ini akan membahas tentang gaya kepemimpinan transformatif yang dijadikan model dalam menjalankan organisasi di lembaga kependidikan.

\section{KONSEP KEPEMIMPINAN DAN KEPEMIMPINAN TRANSFORMA- TIF}

Kepemimpinan merupakan energi pengggerak organisasi. Kepemimpinan juga merupakan energi yang dapat menggerakkan, menuntun dan menjaga aktifitas orang sehingga tujuan organisasi dapat tercapai. Menurut Owens (1995) kepemimpinan merupakan suatu interaksi antara satu pihak sebagai pemimpin dengan pihak yang dipimpin. Kepemimpinan hanya ada dalam proses relasi seseorang dengan orang lain, sehingga tidak ada pengikut menyebabkan tidak ada pemimpin. Dengan demikian, pemimpin yang efektif harus mengetahui bagaimana membangkitkan inspirasi, memotivasi, dan bekerjasama dengan bawahannya. Sehingga, pemimpin pendidikan harus melakukan transformasi kepemimpinan dengan melakukan bimbingan, tuntunan dan anjuran kepada orang yang dipimpinnya agar tujuan lembaga dapat tercapai.

Penerapan pola kepemimpinan transformasional dapat menunjang terwujudnya perubahan sistem kelembagaan. Menurut penulis, kepemimpinan transformatif merupakan salah satu pilihan gaya kepemimpinan di lembaga pendidikan. Hal ini dilakukan untuk mewujudkan lembaga pendidikan yang berkualitas. Kepemimpinan yang bersifat transformasional memiliki penekanan dalam perwujudan visi dan misi, yang jelas, pengunaan komunikasi secara efektif, pemberian rangsangan intelektual, serta perhatian pribadi terhadap permasalahan individu anggota organisasinya. Dengan penekanan tersebut, pemimpin di lembaga pendidikan akan mampu meningkatkan kinerja stafnya dalam rangka mengembangkan kualitas lembaga.

Menurut penulis, upaya utama aktifitas kepemimpinan adalah melakukan tranformasi. Kepemimpinan transformasional menuntut pemimpin yang mampu berkomunikasi dengan baik, terutama komunikasi persuasif, dan adanya motivasi berprestasi baik yang dimiliki pimpinan maupun situasi yang diciptakan pimpinan kepada personil lembaganya. Komunikasi persuasif dapat dikembangkan melalui dialog antara atasan dengan bawahan mengenai pekerjaan dalam organisasi ataupun keluhan pribadi yang dirasakan oleh atasan. Karena dialog merupakan salah satu komponen utama dalam seni persuasi (Nur, 2009). Perilaku kepemimpinan bukanlah berada pada konteks yang kosong, melainkan ditentukan oleh multifaktor. Salah satunya adalah dorongan dari dalam diri pemimpin untuk berkinerja setinggi mungkin.

Esensi transformasi adalah mengubah potensi menjadi energi nyata. Pemimpin di lembaga pendidikan yang mampu melakukan transformasi kepemimpinan, berarti telah mampu mengubah potensi institusinya menjadi energi, untuk meningkatkan mutu proses dan hasil pendidikannya. Karen kepemimpinan transformatif dapat diartikan sebagai bentuk atau gaya yang digunakan pimpinan untuk mempengaruhi bawahannnya mencapai tujuan yang diinginkan (Nur, 2009). 
MODEL KEPEMIMPINAN TRANSFORMASI DI LEMBAGA PENDIDIKAN

Model transformasional seorang pemimpin akan mempengaruhi kinerja bawahan. Karena seorang pemimpin transformasional memiliki visi yang jelas dan gambaran yang holistik mengenai organisasi di masa depan ketika semua tujuan telah tercapai (Owens, 1995). Model transformasional sebagai berikut:

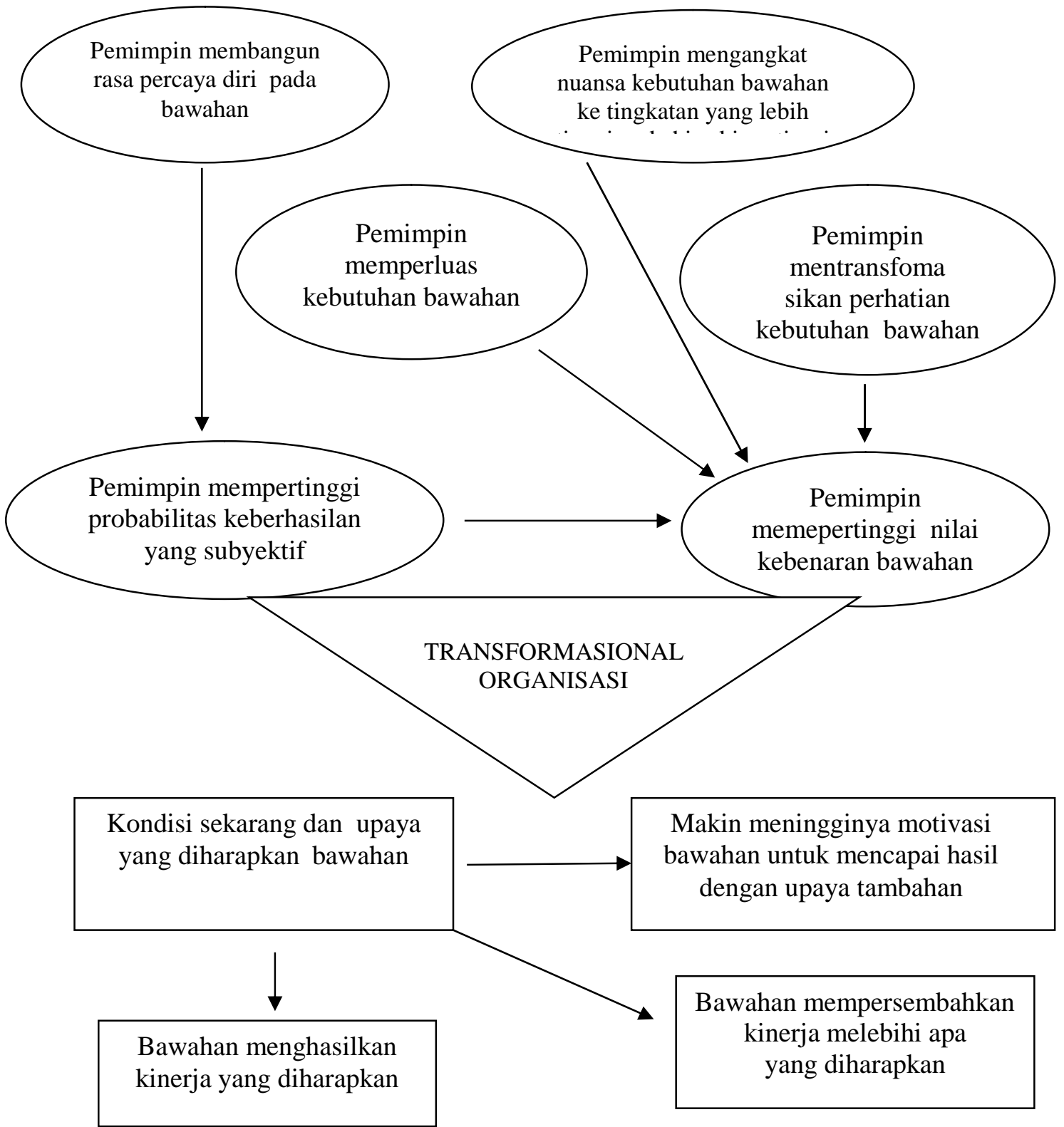

Gambar. Model Kepemimpinan Transformasional (Owens, 1995)

Menurut penulis, gambar di atas memperlihatkan bahwa pemimpin yang transformatif memberi peluang berkembangnya potensi diri setiap orang dalam organisasi. Hal ini dilakukan dengan cara memberikan penghargaan, memperhatikan dan mendorong rasa percaya diri pada bawahannya untuk meujudkan kinerja terbaik yang bisa mereka lakukan (Nur, 2009). Manusia dalam organisasi akan tumbuh dan berkembang kemampuan dan kreatifitasnya manakala pimpinan menciptakan suasana tersebut, sehingga kalau di kenal ada 4 
kelompok manusia dalam organisasi yaitu (1) mampu, dan mau menunjukkan kinerja optimalnya; (2) mampu dan tidak mau menunjukkan kinerja optimalnya; (3) tidak mampu dan mau belajar dan bekerja optimal dan (4) tidak mampu namun tidak mau belajar dan bekerja optimal. Selanjutnya, Kartono (2003) mengatakan bahwa superioritas pribadi seorang pemimpin menjadi unsur kekuatan dirinya. Kekuatan dimaksudkan di sini menyangkut kemampuan pemimpin dalam belajar dan mempelajari karakteristik bawahannya dan mengarahkannya sesuai dengan keberagaman individual yang dimiliki.

Ciri kepribadian (Sayle dan Kumar, 2006), harus dimiliki oleh pemimpin yang dinamis. Faktor ini akan membetuk pemimpin yang kuat dan bersemangat dalam meraih sukses. Beberapa ciri tersebut adalah:

1. Self acknowledgement; Seorang pemimpin besar harus bisa memahami diri sendiri. Cara memandang diri sendiri dilakukan dalam situasi dan lingkungan yang beragam. Karena pemahaman ini akan membantu seorang pemimpin mengetahui bakat atau talenta yang mereka punyai, sehingga juga mampu untuk memanfaatkannya.

2. Open minded; Pemimpin efektif adalah seorang yang berpikiran terbuka terhadap saran dan kritikan. Karena, keduanya akan akan mempengaruhi kinerja.

3. Semangat untuk mengembangkan diri dan terus belajar; Seorang pemimpin yang dinamis dapat memberikan perhatian penuh terhadap pekerjaan, tugas dan organisasi yang dipimpinnya. Mereka tahu betul pekerjaan dan apa yang dapat mereka kerjakan dengan baik serta selalu belajar untuk menjadi lebh baik dan lebih baik lagi. Hampir semua pemimpin cenderung mempunyai ke- mauan untuk berubah berdasarkan informasi baru.

4. Risk Taker dan curious; Pemimpin adalah sosok yang mempunyai sifat ingin tahu dan berani mengambil resiko. Seorang pemimpin besar mempunyai jiwa petualang dalam hal yang positif. Selanjutnya, mereka mempunyai rasa ingin tahu dan ketertarikan yang besar terhadap ide dan pemikiran baru.

5. Kosentrasi; Seorang pemimpin sukses mempunyai ketahanan diri yang sangat tinggi. Selain itu, seorang pemimpin yang sukses mempunyai tingkat kosentrasi yang tinggi terhadap pekerjaan, tugas, organisasi, dan sasaran-sasaran mereka.

6. Mengambil hikmah dari setiap tekanan atau kejadian yang kurang menyenangkan; Hampir semua pemimpin adakalanya mengalami kemunduran, bahkan kegagalan dalam mencapai tujuan dan mengatasi krisis. Tetapi kegagalan tidak membuat mereka jera dan bersikap pasrah, melainkan semakin memacu mereka untuk mempersiapkan diri bagi sukses di masa datang.

7. Keseimbangan antara tradisi dan perubahan; Pemimpin yang efektif selalu berusaha mengatur keseimbangan antara tradisi dan perubahan yang terjadi. Seorang pemimpin yang ditempatkan di suatu daerah baru harus mempelajari adat istadat dan kebiasaan yang berlaku di tempat tersebut, agar tidak berbuat kesalahan. Ia harus membina hubungan antara budaya dan perubahan tetapi tidak terjerat olehnya.

8. Openness; Pemimpin harus mempunyai keinginan tulus untuk menata ulang dan melakukan perubahan positif pada organisasi yang dipimpinnya. Taktik ini dapat dilakukan dengan cara menyediakan "kotak saran" untuk semua orang yang ingin menyampaikan kritik, saran dan 
informasi secara bebas tanpa batasan dan akan dibahas pada setiap pertemuan yang rutin diadakan. Cara ini, adalah kunci untuk terciptanya perubahan dalam organisasi yang dipimpinnya.

9. Bekerja dalam sistem; Pemimpin efektif akan menyadari bahwa ia tidak dapat bekerja sendirian, dan tidak akan berhasil untuk menangani setiap masalah satu per satu. Ia membutuhkan tim yang terdiri dari staf yang berkerja sesuai dengan dengan sistem dan prosedur yang telah ditetapkan agar dapat berjalan dengan lancar.

10. Memberi contoh dan menjadi mentor bagi bawahannya; Pemimpin efektif harus mampu memberi contoh baik dan menjadi panutan serta mentor yang baik bagi rekan-rekan kerjanya di samping belajar dari kehidupan dan pengalamannya.

\section{DAFTAR RUJUKAN}

Eidwar, 2008. Kontribusi Kepemipinan Kepala sekolah dan Motivasi Berprestasi terhadap Kinerja Guru SMP Negeri di Kota Sawah Lunto. Padang: Tesis.

Kartono, Kartini. 2003. Pemimpin dan Kepemimpinan. Bandung: PT Raja grafindo Persada.

Nur, Agustiar Syah, 2009. Bahan Perkuliahan pada Mata Kuliah Kepemimpinan Pendidikan. Padang: Pascasarjana UNP

Owens R.G 1995. Organizational Culture in Education. 5 th edition. Boston: Allyn and Bacon.

Daftar Indeks

\section{KESIMPULAN}

Kepemimpinan transformasional merupakan salah satu pendekatan kepemimpinan yang diperlukan oleh setiap organisasi umumnya, lembaga pendidikan khususnya. Pemimpin transformatif adalah sosok yang harus tanggap terhadap potensi sumber daya yang dimiliki organisasi terutama pada sumber daya manusianya. Pemimpin transformatif mampu mengarahkan semua potensi untuk pencapaian tujuan organisasi secara optimal. Kepemimpinan pendidikan transformatif mampu "membaca" perubahan yang terjadi di luar organisasi yang juga menuntut adanya perubahan dalam organisasi dan mampu menggerakkan bawahannya sesuai visi dan misi organisasi.

Robbin, Stephen P. 1993. Organizational Behavior. 6th edition. New Yersey Prentice Hall. Inc. Internet Edition

Yulisna, 2008. Kontribusi Motivasi Kerja dan Kredibilitas Kepala Sekolah Terhadap Kinerja Guru Sekolah Menegah Pertama Negeri di Kota Sawah Lunto, UNP: Tesis

Sayle, Bart and Kumar, Surinder. 2006. Reading The Best Train. A Leadership plan for Explosive Growth. Penguin Group USA.

kosentrasi, 66

lembaga, 79, 64, 65, 67

efektif, 79, 64, 66, 67 
organisasi, 79, 64, 65, 66, 67

Pemimpin, 79, 64, 65, 66, 67

pendidik, 79, 67

penelitian, 64

perubahan, 64, 67 potensi, 65, 66, 67

prestasi, 79

sekolah, 79, 64, 67

transformatif, 79, 64, 65, 66, 67 